\title{
PENGARUH KEPUTUSAN INVESTASI DAN KEPUTUSAN PENDANAAN TERHADAP NILAI PERUSAHAAN PADA SEKTOR PROPERTY \& REAL ESTATE YANG TERDAFTAR DI BEI
}

\author{
Desi Novalia, Aminar Sutra Dewi \\ Sekolah Tinggi Ilmu Ekonomi KBP \\ desinovalia23@gmail.com
}

\begin{abstract}
The overall economic slowdown has impacted the property sector, which caused the decline in property sector sales due to the lack of public interest to make the demand for property loans slow down. This study aims to test whether the Investment Decision and Decision of the Pendaanaan affect the Value Company. Population in this research is company of property \& real estate sector listed in BEI period 2013-2016. The sample in this study using purposive sampling technique amounted to 41 companies studied. Data analysis used in this research is classical assumption test and for hypothesis test using multiple regression analysis with the help of E-VIEWS 8. The result of this research indicates that Investment Decision has positive and significant effect to Company Value. while the Funding Decision also has a positive and significant impact on Corporate Value.
\end{abstract}

Keywords : Investment Decision, Funding Decision, the Firm Value

\section{PENDAHULUAN}

Nilaiperusahaan adalah suatu hal yang sangat penting bagi seorang manajer maupun bagi pihak investor. Manajer memandang nilai perusahaan menggambarkan suatu pencapaian target atas hasil kerja yang telah dicapainya. Jika seorang manajer mampu untuk meningkatkan nilai perusahaan maka manajer tersebut telah melakukan kinerja baik bagi perusahaan. Selain itu, tanpa disengaja manajer ini telah mampu untuk meningkatkan kesejahteraan bagi pemegang saham yang merupakan tujuan perusahaan. Dengan meningkatnya nilai suatu perusahaan maka pandangan investor terhadap perusahaan juga baik, jika pandangan investor sudah baik, maka investor tersebut ingin menanamkan modalnya, hal tersebut diikuti dengan meningkatnya nilai dari suatu perusahaan.(Setiana, 2007)

Price Book Value (PBV) merupakan alat ukur nilai perusahaan, Rasio ini membandingkan harga saham terhadap nilai bukunya. rasio PBV besar dari satu menunjukkan nilai bukunya lebih kecil dari pasar saham, dapat disimpulkan bahwa perusahaan tersebut baik.(Sari, 2013)

Perkembangan perekonomian di masa sekarang ini mempengaruhi laju pertumbuhan ekonomi secara makro di Indonesia. Perlambatan ekonomi secara menyeluruh yang terjadi sejak tahun lalu menyebabkan berkurangnya penjualan sektor property di Indonesia dalam beberapa tahun belakangan. Hal ini berarti 
perkembangan sektor properti saling mempengaruhi terhadap sektor lainnya. Seperti industri properti nasional mengalami rintangan yang cukup berat mempengaruhi beberapa hal, diantaranya adalah pelambatan pertumbuhan ekonomi, pelambatan ekonomi dikerenakan oleh kurangnya minat beli masyarakat yang membuat permintaan terhadap kredit properti mengalami pelambatan, menjadi perhatian banyak pihak, termasuk juga dalam kalangan lembaga keuangan dan perbankan. Properti adalah salah satu sektor yang kemampuannya memiliki suatu dorongan bagi pertumbuhan ekonomi.

Dengan demikian, perusahaan dibidang property dan real estate akan memperhatikan nilai perusahaan dimata publik untuk mendorong perusahaan disektor tersebut. Maka dapat diketahui bahwa Nilai perusahaan secara langsung bisa berdampak pada peningkatan pemilik saham secara optimal apabila harga saham perusahaan meningkat, maka untuk tercapainya Nilai perusahaan yang tinggi para pemegang saham mempercayai pengelolaannya kepada orang yang lebih profesional yang lebih tinggi ilmunya, seperti seorang manajer ataupun komisaris dalam struktur organisasi perusahaan agar para investor memutuskan untuk berinvestasi pada perusahaan tersebut.

Beberapa penelitian terdahulu telah melakukan kajian mengenai Pengaruh keputusan investasi, keputusan pendanaan dan kebijakan dividen terhadap nilai perusahaan Sari (2013). Hasil penelitiannya menunjukan keputusan investasi berpengaruh positif dan signifikan terhadap nilai perusahaan, keputusan pendanaan berpengaruh negatif tidak signifikan terhadap nilai perusahaan, pengaruh positif dan signifikan antara variabel kebijakan dividen terhadap nilai perusahaan. (Sari, 2013)

Selanjutnya Penelitian sejenis juga dilakukan oleh Faridah (2016) dengan judul Pengaruh Keputusan Investasi, Pendanaan, Kebijakan Dividen, Tingkat Suku Bunga terhadap Nilai Perusahaan. Hasil temuan ini menyatakan bahwa adanya pengaruh positif antara keputusan investasi terhadap nilai perusahaan, dan tidak ada pengaruh antara keputusan pendanaan pada nilai perusahaan, variabel kebijakan dividen berpengaruh negatif terhadap nilai perusahaan, selanjutnya tingkat suku bunga tidak mempengaruhi terhadap nilai perusahaan.

Teory sinyal merupakan langkah yang dipilih oleh manajemen perusahaan yang memberikan pedoman bagi investor tentang cara manajemen untuk mencapai tujuan perusahaan merupakan pengertian terhadap teori sinyal. Untuk mendapatkan keuntungan perusahaan berusaha untuk menjauhi penjualan saham dan mencari modal baru dengan cara lain seperti menggunakan hutang.

Perusahaan memiliki motivasi untuk memberitahukan informasi laporan keuangan terhadap pihak eksternal. Motivasi perusahaan untuk memberitahukan informasi karena diperoleh asimetri informasi kepada perusahaan dan pihak luar sebab perusahaan memahami lebih mengetahui tentang perusahaan dan peluang yang akan mendatang dari bagian luar (investor dan kreditor). Kurangnya informasi oleh pihak luar tentang perusahaan mengakibatkan mereka melidungi diri karena membagikan harga yang kecil untuk perusahaan. Perusahaan bisa meningkatkan nilai perusahaan dengan menurunkan kesenjangan informasi.

Nilai perusahaan yaitu gambaran terpilih yang sudah dicapai oleh suatu perusahaan menjadi kepercayaan masyarakat kepada perusahaan sesudah 
melakukanbeberapa proses kegiatan selama beberapa periode, yaitu sejak awal perusahaan berdiri sampai dengan saat ini. Yang diinginkan pemegang perusahaan adalah menambah nilai perusahaan, sebab dengan meningkatnya nilai perusahaan, jadi kemakmuran para pemegang saham juga akan meningkat.(Faridah, 2016)

Investasi merupakan pengorbanan asset yang dimiliki sekarang untuk mendapatkan keuntungan pada waktu yang akan datang dengan tujuan akan mendapatkannilai yang lebih besar. Tujuan utama yang diinginkan oleh investor adalah perusahaan yang berkembang dan dapat memberikan keuntungan hasil yang diharapkan. Hasil penelitian dari Achmad \& Amanah (2014) yang berjudul Pengaruh Keputusan Investasi, Keputusan Pendanaan, Kebijakan Dividen Dan Kinerja Keuangan Terhadap Nilai Perusahaan berpendapat bahwa keputusan investasi berpengaruh terhadap nilai perusahaan yang menyatakan bahwa keputusan investasi mempengaruhi dan signifikan terhadap nilai perusahaan. Pada penelitian Hasnawati (2005) yang berjudul Dampak Set Peluang Investasi Terhadap Nilai Perusahaan Publik di Bursa Efek Jakarta, dengan hasil penelitiannya yang menyatakan bahwa keputusan investasi berpengaruh positif terhadap nilai perusahaan. Maka dapat disimpulkan bahwa hipotesis pertama adalah diduga Keputusan investasi berpengaruh positif terhadap nilai perusahaan.

Keputusan pendanaan yaitu keputusan tentang sumber dana yang hendak dipergunakan oleh perusahaan. Sumber dana tersebut terbagi 2 yaitu sumber biaya internal dan sumber biaya eksternal. Sumber dana eksternal yang diperolehpada perusahaan adalah hutang dan modal sendiri. Seorang pemimpin harusbisa untuk mempertimbangkan komposisi antara pe manfaatan hutang dengan modal sendiri, sebabuntuk mengetahui komposisi pendanaan optimal yangbisadipengaruhi Nilai perusahaan.(Setiana, 2007). Hasil pengujian Rakhimsyah (2011) menyatakan bahwa keputusan pendanaan berpengaruh terhadap nilai perusahaan. Juga mengemukakan yaitu keputusan pendanaan berpengaruh positif terhadap Nilai perusahaan. Selanjutnya penelitian dari Sari (2013) dengan penelitiannya pengaruh keputusan investasi, kebijakan dividen dan keputusan pendanaan terhadap nilai perusahaan, yang membuktikan bahwa hasil hipotesisnya tentang keputusan pendanaan adanya hubungan positif dan signifikan terhadap nilai perusahaan. Maka dapat disimpulkan bahwa hipotesis kedua adalah diduga Keputusan pendanaan berpengaruh positif terhadap nilai perusahaan.

\section{METODE PENELITIAN}

Jenis penelitian ini menggunakan penelitian berupa metode kuantitatif. Penelitian kuantitatif adalah metode penelitian dimana data peneliti berbentuk angka-angka dan analisis menggunakan statistik (Sugiyono, 2015).

Objek penelitian yaitu sasaran ilmiah untuk memperoleh data dengan tujuan dan manfaat tertentu tentang suatu objektif, realibel dan valid mengenai hal atau variabel(Sugiyono, 2015). maka objek yang diambil pada penelitian ini yaitu perusahaan sektor property dan real estate yang tercatat Bursa Efek Indonesia (BEI) Periode 2013-2016. Sebab BEI merupakan pusat laporan yang akurat mengenai perusahaan yang go public.

Populasi adalah wilayah generalisasi yang didalamnya terdapat objek/subjek yang memiliki karakteristik dan kuantitas tertentu yang telah 
ditentukan oleh peneliti dalam memahami dan selanjutnya diambil kesimpulannya (Sugiyono, 2015). Populasi yang dilakukan dalam penelitian ini adalah perusahaan sektor property \& real estate yang terdaftar di Bursa efek Indonesia (BEI) selama periode 2013-2016 adalah berjumlah 45 perusahaan.

Sampel merupakan bagian yang terkecil dari banyaknya karakteristik yang diperoleh dalam populasi,jadi sampel yang ditarik dari populasi harus benar representatif atau bisa mewakili (Sugiyono, 2015).

Penelitian ini menggunakan sampel perusahaan sektor property \& real estate yang terdaftar di Bursa Efek Indonesia (BEI) pada tahun 2013-2016 yaitu dengan mengambil perusahaan tersebut dengan memiilih menggunakan metode purposive sampling.

Adapun kriteria pengambilan sampel dan jumlah sampel pada penelitian ini dapat dilihat pada tabel berikut :

Tabel 1

Tabulasi Pengambilan Sampel Menggunakan Purposive Sampling

\begin{tabular}{|l|c|}
\hline \multicolumn{1}{|c|}{ Keterangan Jumlah } \\
\hline $\begin{array}{l}\text { Perusahaan property dan real estate yang tercatat di } \\
\text { Bursa Efek Indonesia (BEI) periode 2013-2014 }\end{array}$ \\
\hline $\begin{array}{l}\text { Perusahaan yang tidak menyediakan data secara } \\
\text { keseluruhan sesuai variabel selama periode } \\
\text { pengamatan }\end{array}$ & 45 \\
\hline Jumlah sampel peneliti & 41 \\
\hline Jumlah observasi & $41 \times 5=164$ \\
\hline
\end{tabular}

Sumber : $\underline{w w w . i d x . c o . i d}$

Jenis data yang digunakan pada penelitian ini yaitu data kuantitatif. Data kuantitatif merupakan penelitian pengujian teori, maka ada keabsahan untuk menulis teori sebagai penjelasan atau jawaban teoritis atas masalah atau pertanyaan penelitian, atau nilai variabelnya yang dapat dinyatakan secara angka dan kuantitatif.(Silalahi, 2015).

Sumber data yang dipakai adalah bersumber dari data sekunder. Data sekunder adalah suatu data yang diterima dalam bentuk yang telah ada, dan data tersebut sudah digabungkan dan diolah oleh pihak lain, biasanya dalam bentuk publikasi (Suryani, 2015). Data sekunder yang digunakan pada penelitian ini didapatkan dari data laporan keuanganyang sudah dipublikasikan oleh Bursa Efek Indonesiayang dapat di akses melalui www.idx.co.id.

Teknik pengumpulan data yang dipakai dalam penelitian ini adalah studi pustaka, yaitu telah melakukan eksplorasi dan mengkaji berbagai literatur pustaka yang relevan dengan penelitian. Dan dokumentasi, yaitu memilih dan mengumpulkan data yang disediakan BEI. Data yang tersedia berupa laporan keuangan. 
Tabel 2

Defenisi Operasional Variabel

\begin{tabular}{|c|c|c|c|}
\hline Variabel & Definisi & Pengujian & Sumber \\
\hline $\begin{array}{l}\text { Keputusan } \\
\text { investasi } \\
\text { (X1) }\end{array}$ & $\begin{array}{l}\text { Perbandingan } \\
\text { antara harga saham } \\
\text { perusahaan dengan } \\
\text { EPS perusahaan. }\end{array}$ & $\mathrm{PER}=\frac{\text { harga saham }}{\text { earning per share }}$ & $\begin{array}{l}\text { Jurnal } \\
\text { Akuntansi dan } \\
\text { Auditing } \\
\text { Indonesia }\end{array}$ \\
\hline $\begin{array}{l}\text { Keputusan } \\
\text { pendanaan } \\
(\mathrm{X} 2)\end{array}$ & $\begin{array}{l}\text { Perbandingan total } \\
\text { hutang perusahaan } \\
\text { dengan total } \\
\text { ekuitas } \\
\text { perusahaan. }\end{array}$ & $\mathrm{DER}=\frac{\text { total hutang }}{\text { total ekuitas }}$ & $\begin{array}{l}\text { Jurnal } \\
\text { Akuntansi dan } \\
\text { Auditing } \\
\text { Indonesia }\end{array}$ \\
\hline $\begin{array}{l}\text { Nilai perusahaan } \\
\text { (Y) }\end{array}$ & $\begin{array}{l}\text { Perbandingan } \\
\text { harga saham } \\
\text { perusahaan dengan } \\
\text { nilai buku }(\mathrm{BV})\end{array}$ & $\mathrm{PBV}=\frac{\text { hargasaham }}{\text { nilaibukusaham }}$ & $\begin{array}{l}\text { Jurnal } \\
\text { Akuntansi dan } \\
\text { Auditing } \\
\text { Indonesia }\end{array}$ \\
\hline
\end{tabular}

Teknik Analisis Data

\section{Statistik Deskriptif}

Menurut Sugiyono (2015) statistik deskriptif merupakan statistik yang digunakan untuk menguraikan atau memberi cerminan terhadap objek yang digunakan melalui data sampel atau populasi sebagai halnya tidak membuat analisa dan menarik simpulan yang resmi untuk umum yang terdiri dari median, mean, maximum, minimum, varians.

\section{Uji Asumsi Klasik \\ Uji Normalitas}

Pada pengamatan ini digunakan uji statistik Jarque-Bera untuk menganalisa apakah residual berdistribusi normal yang menilai perbandingan skewness dan kurtosis residual dan membandingkan dengan data bersifat normal (Winarno 2015). Hasil uji normalitas dengan uji statistik Jarque-Bera lebih kecil dari 2 atau probability > 0,05 (5\%) dan sebaliknya jika nilai probability Jarque-Bera $<0,05(5 \%)$ maka data tak terdistribusi secara normal.

\section{Uji Multikolinearitas}

Uji multikolinieritas bermaksud untuk melihat apakah ada atau tidak hubungan antara sesama variabel independen. Jika nilai Correlations Matriks diantara tiap-tiap variabel bebas $>0,8(80 \%)$ maka terjadi gejala multikolinieritas dan jika variabel bebas $<0,8(80 \%)$ maka terbebas dari gejala multikolinieritas.

\section{Uji Heteroskedastisitas}

Uji heteroskedastisitas berfungsi untuk membuktikan apakah pada model regresi terdapat perbedaan variance dari residual satu pengamatan ke pengamatan yang lain (Sitompul, 2008). Hasil Uji Heteroskedastisitas menggunakan Uji Glejser adalah uji yang mirip dengan Uji Park, Namun perbedaannya hanya pada variabel dependennya, pada Uji Park menggunakan In(residu $\left.{ }^{2}\right)$ sebagai variabel dependen, pada Uji Glejser variabel ini ditukar dengan nilai absolut residual. Uji glejser yaitu jika nilai probabilitas $F$ hitung $>\alpha=0,05$ maka tidak terjadi gejala heteroskedastisitas dan sebaliknya jika $F$ hitung $<\alpha=0,05$ maka terdapat gejala heteroskedastisitas. 


\section{Analisis Regresi Linear Berganda}

Pada pengujian analisis regresi linear berganda yang dilakukan untuk menguji pengaruh variabel independen yaitu keputusan investasi dan keputusan pendanaaan terhadap variabel dependen Nilai perusahaan. Persamaan model regresi dari penelitian ini adalah :

$$
\begin{array}{ll}
\text { Dimana : } & \\
\mathbf{Y} & =\boldsymbol{\alpha}+\boldsymbol{\beta} 1 \mathbf{x} \mathbf{1}+\boldsymbol{\beta} 2 \mathbf{x} \mathbf{2}+\mathbf{e} \\
\alpha & =\text { Bilangan konstanta } \\
\mathrm{Y} & =\text { Price Book Value }(P B V) \\
\beta 1, \beta 2 & =\text { koefisien regresi berganda } \\
\mathrm{X} 1 & =\text { Price Earning Ratio }(P E R) \\
\mathrm{X} 2 & =\text { Debt to Equity Ratio }(D E R) \\
\mathrm{e} & =\text { Error }
\end{array}
$$

\section{Uji Hipotesis}

Uji Hipotesis merupakan jawaban sementara terhadap rumusan masalah penelitian, sebab rumusan masalah penelitian sudah dinyatakan pada jenis kalimat pertanyaan (Sugiyono, 2015). Jadi dapat diartikan bahwa uji hipotesis sebuah jawaban teoritis dari pertanyaan rumusan masalah.

\section{Uji F (Uji Silmutan)}

Uji Hipotesis ini berfungsi untuk membuktikan atau menguji apakah koefisien regresi yang diperoleh signifikan (berbeda nyata). Dengan penelitian

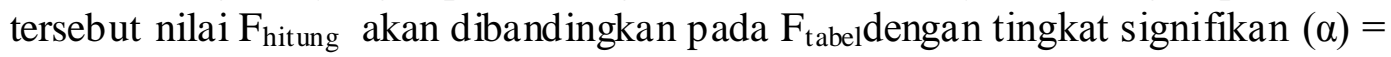
5\% (Erari 2014)

\section{Uji t (uji persial)}

Uji t digunakan untuk menguji apakah secara parsial semua variabel yang dilakukan dalam pengujian tersebut memiliki pengaruh signifikan terhadap harga saham (Sunardi, 2010). (Sitompul, 2008) Uji-t. Pengujian dilakukan dengan 2 arah dengan tingkat keyakinan $95 \%$ serta uji tingkat signifikansi $(\alpha)$ ditentukan sebesar $5 \%$. Dengan kriteria pengujian: Jika $t_{\text {hitung }}>t_{\text {tabel }}$ atau jika nilai $\rho<\alpha$ maka Ho ditolak. Jika $t_{\text {hitung }}<t_{\text {tabel }}$ atau jika nilai $\rho>\alpha$ maka Ho diterima. Kesimpulannya, apabila $t_{\text {hitung }}>t_{\text {tabel }}$, maka Ha diterima dan Ho ditolak. Berarti variabel independen secara parsial berpengaruh pada variabel dependen. Demikian juga sebaliknya, jika $t_{\text {hitung }}<t_{\text {tabel, }}$, berarti Ho diterima dan Ha ditolak, artinya variabel yang bersangkutan tidak berpengaruh pada variabel dependen.

\section{Uji $\mathbf{R}^{2}$ ( Uji koefisien Determinan)}

Pengujian koefisien determinasi dilakukan untuk membuktikan seberapa besar variasi variabel dependen bisa dijelaskan untuk variasi variable independen. Uji koefisien determinan diamati melalui nilai adjusted $\mathrm{R}^{2}$ (Fahruri, 2017). Nilai koefisien determinan adalah diantara nol dan satu. Misalnya koefisien determinasi $\left(\mathrm{R}^{2}\right)=1$, artinya variabel independen menyampaikan seluruh informasi yang dibutuhkan guna melihat variasi variabel dependen. Apabila koefisien determinasi $\left(\mathrm{R}^{2}\right)=0$, artinya variabel bebas tidak bisa menerangkan variabel terikat. 


\section{HASIL DAN PEMBAHASAN}

\section{Uji Statistik Deskriptif Variabel}

Berdasarkan pengujian statistik yang sudah dilakukan terdapat ringkasan hasil dari pengolahan data secara deskriptif yang terlihat pada tabel dibawah ini :

\section{Tabel 3}

Hasil Uji Statistik Deskriptif

\begin{tabular}{llllll}
\hline Variabel & N & Minimun & Maximum & \multicolumn{1}{c}{ Mean } & $\begin{array}{c}\text { Standar } \\
\text { deviasi }\end{array}$ \\
\hline PBV & 164 & 0.12 & 8.30 & 1.63 & 1.49 \\
PER & 164 & -573.72 & 1046.10 & 18.60 & 126.92 \\
DER & 164 & 0 & 2.24 & 0.70 & 0.499 \\
\hline
\end{tabular}

Sumber : output eviews 8

Pada tabel 2 diatas menjelaskan bahwa nilai terendah untuk nilai perusahaan (PBV) adalah sebesar 0.12 terdapat pada RBMS pada tahun 2015 sedangkan nilai tertinggi sebesar 8.30 pada perusahaan PLIN tahun 2016. secara rata-rata nilai perusahaan (PBV) sebesar 1.63. nilai rata-rata 1.63 bermakna bahwa perbandingan antara harga saham dengan nilai buku adalah sebesar 1.63. standar deviasi nilai perusahaan (PBV) sebesar 1.49 dengan jumlah observasi sebanyak 164.

Nilai terendah untuk keputusan investasi (PER) adalah sebesar -573.72 terdapat pada perusahaan LCGP pada tahun 2014 dan nilai tertinggi sebesar 1040.10 terdapat pada perusahaan GAMA tahun 2016 dengan rata-rata 18.60 yang artinya perbedaan pada harga saham perusahaan dengan erning per share (EPS) perusahaan adalah sebesar 18.60. sedangkan standar deviasi keputusan investasi (PER) sebesar 126.92 dengan jumlah observasi 164.

Selanjutnya Nilai terendah untuk keputusan pendanaan (DER) adalah sebesar 0 terdapat pada perusahaan PLIN pada tahun 2013 dan nilai tertinggi sebesar 2.24 terdapat pada perusahaan GMTD tahun 2013 dengan rata-rata 0.70 yang artinya Perbedaan total hutang perusahaan dengan total ekuitas perusahaan adalah sebesar 0.70. sedangkan standar deviasi keputusan pendanaan (DER) sebesar 0,49 dengan jumlah observasi 164 .

\section{Uji Asumsi Klasik}

\section{Uji Normalitas}

Uji normalitas bermaksud untuk melihat apakah pada model regresi data variabel-variabel penelitian terd is tribusi normal. Bentuk regresi yang baik adalah data yang terd istribusi normal dan data terd is tribusi normal dapat dilihat jika probability jarque-Bera >0,05 maka data terdistribusi normal, apabila probability jarque-Bera $<0,05$ berarti data tersebut tidak terd istribusi normal. Berikut adalah hasil pengujian normalitas pada tabel dibawah ini : 
Tabel 4

Hasil Uji Normalitas

\begin{tabular}{cc}
\hline Jarque-bera & $\mathbf{3 . 0 8 3 7 8 5}$ \\
\hline probability & $\mathbf{0 . 2 1 3 9 7 8}$ \\
\hline
\end{tabular}

Sumber : output eviews 8

Data tabel 3 diatas dijelaskan bahwa data penelitian terdistribusi normal setelah melakukan transformasi data dengan menggunakan substansial positive skewness. Dengan nilai jarque-bera 3.083785 (0.213978>0.05). dengan demikian dapat disimpulkan bahwa data sudah Terdistribusi Normal.

\section{Uji Multikolinieritas}

Hasil uji multikolinieritas dengan metode korelasi matriks adalah jika nilai variabel bebas $>0.8$ maka terjadi multikolinieritas. Tetapi jika nilai variabel bebas $<0.8$ maka tidak terjadi multikolinieritas.

\section{Tabel 5}

Hasil Uji Multikoleniaritas

\begin{tabular}{lrr}
\hline \multicolumn{1}{c}{ VARIABEL } & PER & DER \\
\hline PER & 1.000000 & 0.339792 \\
DER & 0.339792 & 1.000000 \\
\hline
\end{tabular}

Sumber : output eviews 8

Dari tabel diatas dapat dilihat nilai korelasi matriks pada dua variabel. Yakni PER terhadap DER sebesar 0.339792. Bisa disimpulkan bahwa pada 2 variabel bebas tidak terjadi multikolinieritas.

\section{Uji Heteroskedastisitas}

Hasil Uji Heteroskedastisitas dengan menggunakan Uji Glejser adalah uji yang mirip dengan Uji Park, Namun perbedaannya hanya pada variabel dependennya, pada Uji Park menggunakan In(residu $\left.{ }^{2}\right)$ sebagai variabel dependen, pada Uji Glejser variabel ini diganti dengan nilai absolut residual. Uji glejser yaitu jika nilai probabilitas $\mathrm{F}$ hitung $>\alpha=0,05$ maka tidak terjadi gejala heteroskedastisitas dan sebaliknya jika $F$ hitung $<\alpha=0,05$ maka terdapat gejala heteroskedastisitas.

\section{Tabel 6}

Hasil Uji Heteroskedastisitas

Sumber : output eviews 8

\begin{tabular}{crrrr}
\hline D Variable & Coefficient & Std. Error & t-Statistic & Prob. \\
\hline C & 0.246946 & 0.037229 & 6.633184 & 0.0000 \\
PER & 0.019978 & 0.027594 & 0.723990 & 0.4701 \\
DER & -0.082885 & 0.047712 & -1.737202 & 0.0843 \\
\hline
\end{tabular}

dari tabel 6 dapat dilihat nilai probability variabel PER sebesar $0.4701>0,05$ yaitu sebesar 0.4701 dan nilai probability variabel DER sebesar $0.0843>0.05$ yaitu sebesar 0.0843 , maka bisa disimpulkan tidak terjadi gejala heteroskedastisitas. 


\section{Analis is Regresi Linear Berganda}

Pada penelitian ini, analisis regresi berganda dilakukan untuk memperkirakan hubungan antara keputusan investasi dan keputusan pendanaan terhadap nilai perusahaan. Hasil dari Analis is Regresi Liniear Berganda bisa dilihat pada tabel berikut :

Tabel 7

Hasil Uji Regresi Linear Berganda

\begin{tabular}{lcccc}
\hline \multicolumn{1}{c}{ Variabel } & Coefficient & Std.Error & T-Statistic & Prob \\
\hline C & 0.009272 & 0.064389 & 0.144002 & 0.8857 \\
PER & 0.112983 & 0.047725 & 2.367356 & 0.0191 \\
DER & 0.286230 & 0.082520 & 3.468628 & 0.0007 \\
Adjusted R-squared & 0.129490 & & & \\
F-Statistic & 13.12326 & & & \\
Prob (F-Statistic) & 0.000005 & & & \\
\hline
\end{tabular}

Pada tabel 7 dapat dilihat hasil nilai regresi linear berganda antara keputusan investasi dan keputusan pendanaan terhadap nilai perusahaan, persamaannya sebagai berikut :

$$
\begin{aligned}
& \mathbf{Y}=\boldsymbol{\alpha}+\boldsymbol{\beta 1} \mathbf{x} 1+\boldsymbol{\beta} 2 \times \mathbf{2}+\mathbf{e} \\
& \mathrm{Y}=0.009272+0.112983 \mathrm{X} 1+0.286230 \mathrm{X} 2+\mathrm{e}
\end{aligned}
$$

Berdasarkan pada model persamaan regresi linier berganda diatas dapat dijelaskan sebagai berikut :

1. Koefisien Regresi keputusan investasi

Nilai regresi keputusan investasi senilai 0.1129 , nilai koefisien regresi ini bersifat positif yang menunjukkan adanya hubungan yang searah atau positif dan signifikan antara variabel keputusan investasi dengan nilai perusahaan sektor property \& real estate yang tercatat di Bursa Efek Indonesia. Hal ini mengindikasikan bahwa semakin baik keputusan investasi yang di dapatkan perusahaan, maka dapat meningkatkan nilai perusahaan sebesar 0.1129 (11.29\%).

2. Koefisien Regresi keputusan pendanaan, besarnya nilai koefisien regresi keputusan pendanaan sebesar 0.2862 , nilai koefisien regresi ini bersifat positif dan signifikan yang menunjukkan ada hubungan yang searah atau hubungan positif antara variabel keputusan pendanaan dengan nilai perusahaan sektor property \& real estate yang tercatat di Bursa Efek Indonesia. Hal ini menunjukkan bahwa keputusan pendanaan yang baik, maka dapat meningkatkan nilai perusahaan sebesar 0.2862 (28.62\%).

\section{Hasil Pengujian Hipotesis}

\section{Uji f (Uji Secara Simultan)}

Dari tabel 7 dihasilkan $F$-Statistik sebesar 13.12326 dengan nilai signifikansi probability $F$-Statistik sebesar 0.000005 lebih rendah pada tingkat signifikansi 0.05 sehingga dapat disimpulkan model regresi yang diestimasi layak digunakan untuk pengaruh keputusan investasi dan keputusan pendanaan terhadap nilai perusahaan.

Uji t (Uji Secara Persial)

Uji $\mathrm{t}$ menjelaskan pengaruh variabel independen sebagai individu terhadap variasi variabel dependen. Pengujian dilakukan jika $t_{\text {hitung }}>t_{\text {tabel }}$ atau 
jika nilai $\rho<\alpha$ maka $\mathrm{H} 0$ ditolak. Jika $t_{\text {hitung }}<t_{\text {tabel }}$ atau jika nilai $\rho>\alpha$ maka H0 diterima artinya secara parsial variabel bebas mempunyai pengaruh yang signifikan pada variabel terikat dan sebaliknya. Dimana variabel independen atau variabel bebasnya adalah keputusan investasi (PER) dan keputusan pendanaan (DER) sedangkan variabel dependen atau variabel terikatnya adalah nilai perusahaan (PBV). Keputusan investasi menunjukkan $t_{\text {hitung }}$ $2.367356>t_{\text {tabel }} 1.97472$ dengan nilai yang signifikan 0.0191 kecil dari alpha 0.05 dan koefisien $\beta$ sebesar 0.112983 menunjukkan nilai positif. Maka keputusan investasi berpengaruh positif dan signifikan terhadap nilai perusahaan yang diukur melalui PBV.

Keputusan pendananaan menunjukkan $\mathrm{t}_{\text {hitung }} 3.468628>\mathrm{t}_{\text {tabel }} 1.97472$ dengan nilai yang signifikan 0.0007 kecil dari alpha 0.05 dan koefisien $\beta$ sebesar 0.286230 menunjukkan nilai positif. Jadi keputusan pendanaan berpengaruh positif dan signifikan terhadap nilai perusahaan yang diukur melalui PBV.

Uji $\mathbf{R}^{2}$ (Uji Determinan)

Nilai Adjusted R-Squared pada tabel 7 diatas sebesar 0.1295 menunjukkan bahwa proporsi pengaruh keputusan investasi dan keputusan pendanaan pada nilai perusahaan berjumlah $12.95 \%$ artinya pengaruh keputusan investasi dan keputusan pendanaan terhadap nilai perusahaan sebesar $12.95 \%$ sedangkan sisanya $87.05 \%$ dipengaruhi oleh variabel yang bukan termasuk didalam model regresi, sesuai tingkat suku bunga, kebijakan dividen dan struktur modal.

\section{Pembahasan}

\section{Pengaruh Keputusan Investasi Terhadap Nilai Perusahaan}

Keputusan investasi berpengaruh signifikan dan positif terhadap nilai perusahaan terhadap perusahaan property \& real estate yang terdaftar di BEI pada periode 2013-2016. terlihat dari hasil uji t dimana nilai $t_{\text {hitung }} 2.367356>$ $\mathrm{t}_{\text {tabel }} 1.97472$ dengan nilai yang signifikan 0.0191 kecil dari alpha 0.05 dan koefisien $\beta$ sebesar 0.112983 yang menunjukkan nilai positif. Maka bisa dikatakan hipotesis Ha diterima dan HO ditolak.

Hal ini terjadi karena PER yang tinggi akan menggambarkan perusahaan dalam kondisi sehat dan me mbuktikan bahwa perusahaan memiliki perkembangan yang baik, apabila nilai PER tinggi berarti menjadikan nilai perusahaan akan bertambah terhadap investor. Untuk memperoleh tujuan maka perusahaan harus mampu mengambil keputusan investasi agar memperoleh keuntungan perusahaan di waktu yang akan datang.

Penelitian tersebut didukung dengan teori dari Sartono (2001) yang mengatakan bahwa, apabila perusahaan melaksanakan investasi sekarang maka akan mendapatkan nilaiyang lebih besar dari investasi, maka nilai perusahaan akan meningkat. meningkatnya nilai perusahaan pada investasi tersebut akan tercermin pada meningkatnya harga saham. Hal ini berarti keputusan investasi dapat dinilai dalam hubungannya dengan kemampuan untuk memperoleh keuntungan yang lebih tinggi dari yang targetkan oleh pemilik modal. Pengertian nilai di sini adalah nilai intrinsik investasi yang tidak lain adalah sebesar nilai sekarang dari aliran kas yang diharapkan atas 
investasi.

Hasil penelitian tersebut menjelaskan bahwa penelitian yang dibuat oleh Faridah (2016) dimana hasil pengujiannya yang berjudul pengaruh keputusan investasi, kebijakan deviden, pendanaan, dan tingkat suku bunga terhadap nilai perusahaan, dengan hasil penelitian yang memperlihatkan bahwa keputusan investasi berpengaruh positif dan signifikan terhadap nilai perusahaan,

Selanjutnya penelitian dari Pamungkas (2013) yang berjudul pengaruh keputusan investasi, keputusan pendanaan dan kebijakan deviden terhadap nilai perusahaan. Dengan hasil penelitiannya yang menjelaskan bahwa hipotesisnya yang menyatakan keputusan investasi berpengaruh positif dan signifikan terhadap nilai perusahaan.

\section{Pengaruh Keputusan Pendanaan Terhadap Nilai Perusahaan}

Dari hasil uji statistik (uji t) memperlihatkan bahwa keputusan pendanaan berpengaruh signifikan serta bersifat positif terhadap nilai perusahaan pada perusahaan property \& real estate yang terdaftar di Bursa Efek Indonesia periode tahun 2013-2016. terlihat dari hasil uji t dimana nilai $\mathrm{t}_{\text {hitung }} 3.468628>\mathrm{t}_{\text {tabel }} 1.97472$ dengan nilai yang signifikan 0.0007 kecil dari alpha 0.05 dan koefisien $\beta$ sebesar 0.286230 menunjukkan nilai positif. Hasil temuan ini menunjukkan bahwa adanya pengaruh DER terhadap nilai perusahaan. Dengan demikian maka bisa dikatakan bahwa Ha diterima dan H0 ditolak.

Hasil tersebut sesuai dengan pendapat yang dikemukan oleh modligani miller bahwa penggunaan hutang akan meningkatkan nilai perusahaan sebab biaya bunga hutang adalah biaya yang mengurangi pembayaran pajak. Dengan adanya pengurangan pajak maka biaya modal perusahaan juga akan berkurang yang nantinya dapat meningkatkan nilai perusahaan.

Hasil penelitian ini sebagaimana pengaruh penelitian yang dilakukan Wijaya dan Wibawa (2010) dimana penelitiannya yang berjudul pengaruh keputusan investasi, keputusan pendanaan, ukuran perusahaan dan kebijkan dividen terhadap nilai perusahaan, yang menunjukkan munculnya pengaruh positif dan signifikan antara keputusan pendanaan terhadap nilai perusahaan.

Selanjutnya penelitian dari Sari (2013) dengan penelitiannya pengaruh keputusan investasi, kebijakan dividen dan keputusan pendanaan terhadap nilai perusahaan, yang membuktikan bahwa hasil hipotesisnya tentang keputusan pendanaan adanya hubungan positif dan signifikan terhadap nilai perusahaan.

\section{SIMPULAN}

Menurut hasil penelitian dan pembahasan yang sudah dilakukan lebih dahulu, jadi dapat diperoleh kesimpulan seperti berikut ini:

1. Berdasarkan uji t, hasil penelitian memperlihatkan bahwa keputusan investasi (PER) berpengaruh positif dan signifikan terhadap nilai perusahaan. Hal ini terjadi lantaran PER yang tinggi akan memberikan gambaran bahwa perusahaan dalam kondisi sehat dan memberitahukan bahwa perusahaan memiliki pertumbuhan yang baik, jadi apabila PER semakin tinggi maka akan 
membuat nilai perusahaan akan naik dihadapan para investor. Maka dapat disimpulkan bahwah hipotesis Ha diterima dan Ho ditolak.

2. menurut uji t, pada variabel keputusan pendanaan (DER) hasilnya pengaruh positif dan signifikan terhadap nilai perusahaan. Yang artinya keputusan pendanaan berpengaruh pada nilai perusahaan dimata pasar, dimana nilai perusahaan akan lebih tinggi jika sumber dana yang dimiliki perusahaan bersumber pada modal sendiri. Dengan demikian maka dapat disimpulkan bahwa Ha diterima dan Ho ditolak.

\section{UCAPAN TERIMA KASIH}

Dengan selesainya penulisan artikel ini, penulis mengucapkan terima kasih kepada pihak-pihak yang membantu selama proses penulisan. Kpd Yth: Bapak Febryandhie Ananda, SE, Msi. selaku ketua STIE'KBP" Padang. Ibu Febsri Susanti, SEI, MM. selaku ketua Program Studi Manajemen yang telah mengarahkan penulis yang lebih baik. .Ibu Aminar Sutra Dewi, SE, M.Si. sebagai dosen pembimbing dalam pembuatan skripsi dan artikel ini dan penulis banyak berterima kasih atas kesabaran, kepedulian dan kesempatan yang sudah diberikan, penulis berharap kebaikan ibu bisa dibalas oleh Tuhan Yang Maha Esa. Ibu Maria Magdalena, S.Pd, MM sebagai penasehat akademik program studi manajemen. Dan Seluruh bagian yang sudah banyak menolong penulis yang tidak dapat penulis sampaikan satu persatu.

\section{DAFTAR PUSTAKA}

Achmad, s. Lia, \& amanah, 1. (2014). Pengaruh Keputusan Investasi, Keputusan Pendanaan, Kebijakan Dividen Dan Kinerja Keuangan Terhadap Nilai Perusahaan, 3(9).

Afriyeni, A., \& Marlius, D. (2017). Analisis Pengaruh Harga Saham Perdana Terhadap Abnormal Return Yang Diterima Investor Studi Pada Bursa Efek Indonesia. https://doi.org/10.31219/osf.io/8z7hx

Afriyeni, A., \& Marlius, D. (2018). Analisis Pengaruh Informasi Prospektus Perusahaan Terhadap Initial Return Saham Pada Pasar Perdana Di Bursa Efek Indonesia. https://doi.org/10.31219/osf.io/kt6c4

Afriyeni, A., \& Marlius, D. (2019). Analisis Faktor-Faktor Yang Berpengaruh Terhadap Ketepatan Waktu Penyampaian Laporan Keuangan Pada Perusahaan Yang Listing Di Bursa Efek Indonesia. https://oi.org/10.31219/osf.io/rv4qf

Afriyeni, A., \& Marlius, D. (2019). Analisis Tingkat Pengembalian Dan Risiko Investasi (Studi Pada Industri Manufaktur Yang Terdaftar Di Bursa Efek Indonesia). https://doi.org/10.31219/osf.io/cfb92 
Agustin, E., \& Dewi, A. S. (2019). Pengaruh Good Corporate Governance Dan Leverage Terhadap Kinerja Keuangan Perbankan Yang Terdaftar Di Bursa Efek Indonesia. https:/doi.org/10.31219/osf.io/h9xgp

Dewi, A. S. (2016). Pengaruh Ratio Camel terhadap Return Saham Pada PT Bank Mandiri TBK. Pekbis Jurnal, 8(2), 120-129.

Dr. Ulber Silalahi, M. . (2015). Metode Penelitian Sosial Kuantitatif (Edisi Revi). Bandung: PT Refika Aditama.

Erari, A. (2014). Analisis Pengaruh Current Ratio , Debt To Equity Ratio , dan Return On Asset Terhadap Return Saham Pada Perusahaan Pertambangan di Bursa Efek Indonesia. Jurnal Manajemen \& Bisnis, Vol.5(No.2), 175-191.

Fahruri, A. (2017). Pengaruh Corporate Governance, Loan To Deposit Ratio, Non Performing Loan, Inflasi Dan Kurs Terhadap Kinerja Keuangan Perusahaan Perbankan Yang Terdaftar Di Bursa Efek Indonesia Pada Tahun 2007-2010, $x v(1), 63-70$.

Faridah, N. (2016). Pengaruh Keputusan Investasi, Pendanaan, Kebijakan Dividen, Tingkat Suku Bunga Terhadap Nilai Perusahaan. Jurnal Ilmu Dan Riset Akuntansi, 5(2).

Faridah, N., \& Ur. (2016). Pengaruh Keputusan Investasi, Pendanaan, Kebijakan Dividen, Tingkat Suku Bunga Terhadap Nilai Perusahaan, 5(2010).

Hasnawati, s. (2005). Dampak Set Peluang Investasi Terhadap Nilai Perusahaan Publik Di Bursa Efek Jakarta. Jaai, 9(2), 117-126.

Putri, A. D., \& Mayliza, R. (2019). Pengaruh Good Corporate Governance Dan Leverage Terhadap Kinerja Keuangan Pada Perbankan Yang Terdaftar Di BEI. https://doi.org/10.31219/osf.io/b8he7

Melania, V., \& Dewi, A. S. (2019). Pengaruh Good Corporate Governance Terhadap Kinerja Keuangan Dengan Manajemen Laba Sebagai Variabel Intervening Pada Perusahaan Perbankan Yang Terdaftar Di Bursa Efek Indonesia. https://doi.org/10.31219/osf.io/jrped

Rakhimsyah, Leli Amnah. (2011). Pengaruh Keputusan Investasi, Keputusan Pendanaan, Kebijakan Dividen Dan Tingkat Suku Bunga Terhadap Nilai Perusahaan. Jurnal Investasi, 7(1), 31-45.

Rode, C. D., \& Dewi, A. S. (2019). Pengaruh Good Corporate Governance Dan Leverage Terhadap Kinerja Keuangan Perbankan Yang Terdaftar Di Bursa Efek Indonesia. https//doi.org/10.31219/osf.io/rn6cs 
Sari, O. T. (2013). pengaruh Keputusan Investasi, Keputusan Pendanaan Da n Kebijakan Dividen Terhadap Nilai Perusahaan. Mangement Analysis Journal, 2(2), 1-7.

Setiana, R. (2007). Pengaruh Keputusan Investasi, Keputusan Pendanaan, Dan Tingkat Suku Bunga Terhadap Nilai Perusahaan Pada Perusahaan Otomotif Yang Terdaftar Di Bursa Efek Indonesia, 1-10.

Sitompul, S. S. (2008). Analisis Pengaruh Kinerja Keuangan Dan Ukuran Perusahaan Terhadap Harga Saham Pada Perusahaan Infrastructure, Utilities \& Transportation Yang Terdaftar Di Bursa Efek Indonesia.

Sugiyono. (2015). Statistik Nonparametris “untuk penelitian.” (B. R. Setiadi, Ed.). Bandung.

Sunardi, H. (2010). Pengaruh Penilaian Kinerja Dengan Roi Dan Eva Terhadap Return Saham Pada Perusahaan Yang Tergabung Dalam Indeks Lq 45 Di Bursa Efek Indonesia. Jurnal Akuntansi, 2(1), 70-92.

Winarno, W. W. (2015). Analisis Ekonometrika dan Statistika dengan EViews (4th ed.). Yogyakarta: Upp Stim Ykpn. 